\title{
Review on Role of Forest Certification
}

\author{
Marshet Nigatu Gebeyehu* \\ Jimma University, Ethiopia
}

Submission: March 18, 2019; Published: April 22, 2019

*Corresponding author: Marshet Nigatu Gebeyehu, Assistant Researcher in Ethiopian Environment and Forest Research Institute, Jimma Center, Jimma University, Jimma, Ethiopia

\section{Abstract}

Forest Certification is important component in trade of sustainable forest products or promoting trade in legally harvested forest products. It plays a great role in reducing emissions from deforestation and forest degradation. It improves conservation, sustainable management of forests and enhancement of forest carbon stocks. In this paper I tried to overview role of forest certification in Sustainable Forest Management. Forest Certification contains different criteria and it is a market-based mechanism which provides a link between producer and consumer of forest products. It enhances social, economic, environmental and cultural aspects, but this enhancement may not be the same in all region/country

Keywords: Forest certification; Forest management; Role; Criteria; Cost

\section{Introduction}

Forests have a variety of benefits which includes regulate water cycle, stabilize the Soils, moderate climate through storing carbon dioxide, provide habitat for diverse of flora etc. There is widespread evidence from the developed world for forest transition from shrinking to an expanding forest area [1].To have these benefits of forests the forest should exist sustainably throughout the generation, but there is failure in sustainable development because investment in forestry sector is relatively limited, but agricultural investments that affect forests largely through forest clearing are common place [2]. Forest certification is an attempt to identify forest land that is well managed towards a goal of sustainability. Sustainability in this concept includes the ecological, economic, and social aspect of managing forest [3]. It was introduced in the early 1990s to address concerns of deforestation and forest degradation and to promote the maintenance of biological diversity, especially in the tropics. It shares the aim of promoting sustainable forest management with another tool, namely criteria and indicators for sustainable forest management.

The sustainable forest management approaches try to consider institutional reformation and commercialization of forest products and give special recognition and market opportunities to products originated from well managed forest areas to encourage conservation and even enhance forest level. One tools of such value is forest certification [4]. The Forest Stewardship Council provides both sustainable forest management certification and chain-of-custody certification, although the latter presupposes the former. As of January 2004, it had issued only 116 certificates for forest holdings larger than 50,000 ha, but these accounted for $89.2 \%$ of the Forest Stewardship Council certified area. It had certified 451 forest holdings smaller than 50,000 ha by 2004 , an increase of nearly $60 \%$ since the end of 2001 [5].

Landowners who were certified under either Sustainable Forestry Initiative (or Forest Stewardship Council had significantly effective and stronger biodiversity practices than landowners not certified [6]. Forest Certification is a Trade of sustainable forest products or promoting trade in legally harvested forest products. Forest Certification is given attention because of its role in reducing emissions from deforestation, forest degradation, conservation, sustainable management of forests and enhancement of forest carbon stocks in developing countries [7]. Certification can be an important driver in the transition to a greener economy. Shifting public and private investments towards more sustainable forest management can also create new export opportunities for developing countries this shift will minimize the trigger of deforestation and forest degradation. Generally, in this paper I tried to overview role of forest certification in Sustainable Forest Management.

\section{Criteria's for Forest Certification}

Certification schemes for independent verification of improved forest management should be based on the following criteria:

a) Should be Internationally computable frameworks for certification accreditation and standard setting.

b) Compatibility with globally applicable principles that balance economic, ecological and equity dimensions of for- 
est management and meet Global Forest Alliance requirements.

c) Certification decisions free of conflicts of interest from parties with vested interests.

d) The meaningful and equitable participation of all major stakeholder groups in governance and standard setting.

e) Avoidance of unnecessary obstacles to trade.

f) Objective and measurable performance standards that are adapted to local conditions.

g) Transparency in decision making and public reporting.

h) Reliable and independent assessment of forest management performance and chain of custody.

i) Delivery of continual improvement in forest management.

j) Accessibility to and cost-effectiveness for all parties.

k) Voluntary participation [3].

\section{Role of forest certification}

According to [8], Sustainable forest management as a dynamic and evolving concept aims to maintain and enhance the economic, social and environmental value of all types of forests, for the benefit of present and future generations. It is characterized by seven elements, including:

a) Extent of forest resources;

b) Forest biological diversity;

c) Forest health and vitality;

d) Productive functions of forest resources;

e) protective functions of forest resources

f) Socio-economic functions of forests; and

g) Legal, policy and institutional framework.

According to [9], forest certification is a way to verify whether forests are well managed based on a combination of economic, social and environmental indicators. Certification is a market-based mechanism which provides a link between production and consumption of forest products. Like food labels such as organic, forest certification labels communicate to consumers how a product was made, enabling consumers and businesses to make purchasing decisions that benefit people and the environment. For forest owners and managers, certification is a voluntary way to gain market recognition by committing to good forest management practices.

Many studies broadly indicate that there has been much debate research on forest certification impact. In many cases the research has been based on secondary data sources, such as Forest Stewardship Council reports, with very few field studies of impacts [10]. Tools to facilitate the sustainable development have emerged for two basic reasons; - first the people should use the resource and the utilization should be sustainable, second the utilization of resource should be environment friendly [11]. The most well-respected international standards for sustainable forest management were developed by the Forest Stewardship Council, an independent, nongovernmental, nonprofit organization established in 1993 to promote the responsible management of the world's forests. Forest Stewardship Council forest certification standards consists principles that are meant to ensure that forest management is legal according to national and international laws, respects the rights of workers and indigenous people, limits negative environmental impact and protects areas in the forest that are culturally significant or are habitat for endangered plants or animals [12].

There are also certification schemes which primarily focus on the sustainable use and conservation of forest ecosystems and their biodiversity. Agricultural sustainability Network is a coalition of independent non-profit conservation organizations that promote the social and environmental sustainability of agricultural activities by developing standards. Rainforest Alliance holds the Standards \& Policy Secretariat for Sustainable Agriculture Network. Both, Sustainable Agriculture Network and Rainforest Alliance are dedicated to protecting rainforest and other ecosystems and the people and wildlife that depend on them.

Their sustainable agricultural standard states that "Natural ecosystems are integral components of the agricultural and rural countryside. Carbon capture, crops pollination, pest control, biodiversity and soil and water conservation are just some of the services provided by natural ecosystems on farms. Certification processes have generally helped to raise the public image of the indigenous forest community and legitimize their rights to their lands [13].

\section{Cost and benefits impact of forest certification}

Forest certification important for forest management and achieves a market premium for certified logs. [14] assert that a frequent outcome for certified community forestry enterprises has been improved administration and governance. There is a significant increase in number of companies which own the certificate and were interested in buying raw material coming from sustainably managed forest. Especially high-quality hardwoods destined for the export market achieved a price premium of $27 \%$ to $56 \%$. Lower quality timber obtained a price premium $2 \%$ to $30 \%$ [12]. An export sale also has been expanded and certificate allowed the owner to become more attractive on foreign market. Certification is not economically feasible because of high costs of management procedures. The main direct costs of forest management certification are the payments to the certification body. Relatively higher are costs for tropical forests than temperate forests, partly because many certifiers are in temperate countries and partly because tropical forests are complex both ecologically and socially. 
As consumers, businesses and governments become more concerned with their environmental foot prints; markets for certified forest products continue to grow [15]. The main economic benefit of certification is perceived price premium and market access. But this advantage has rather short term run if the supply of certified products increases. Nevertheless, this is a main driver (problem) for some pioneers of certification, especially in the tropics However, in case of tropical timber for which demand is still very high and even exceeds supply in some export markets. In the case when certification became a basic requirement for timber suppliers in some markets and market segments buyers may not be willing to pay any extra for certification although certification adds value to the product and gives evidence of the environmental quality of the product. The enterprises are often unable to meet expected market benefits because of barriers in export channels. Therefore, benefits which they can find are indirect such as improvements in administration and management [14].

\section{Conclusion}

Forest certification has both opportunity and limitation in addressing sustainable forest management. Certification can enhance social, cultural, economic and environmental aspects, but this enhancement may not be the same in all region/country. Many studies indicated that Forest certification improved sustainable forest management; with the greatest contributions to environmental protection, add values to forest product, increased number of companies for certified products, improved livelihood of forest dependent people, secure land tenure system, and reduce conflict in resource use. However, forest certification is challenging for forest landowners in environmental investments, need high inputs, difficult to access the tools and low awareness in developing countries. Generally, forest certification in sustainable forest management can play great role which may be negative or positive impact on social, cultural economic and environ.

\section{Acknowledgement}

I would like to thank Juniper publisher for supporting us to publish our work.

\section{References}

1. Mather AS (1992) The Forest Transition. The Royal Geographical Society 24(4): 367-379.

2. Guillozet K, Bliss JC (2011) Household livelihoods and increasing foreign investment pressure in Ethiopia's natural forest. pp. 1-25.

3. Rickenbach, Fletcher, Hansen (2000) An introduction of forest certification.

4. Richards M (2004) Certification in complex socio-political settings: Looking forward to the next decade. Forest Trends, Washington D.C, USA.

5. Till S, Ulrike G (2011) Forest Coffee Certification in Ethiopia: Economic Boon or Ecological Bane.

6. Hagan JM, Irland LC, Whitman AA (2005) Changing timberland ownership in the Northern Forest and implications for biodiversity.

7. Muthoo M (2012) Forest certification and the green economy. Florida, America: FAO, pp. 1-7.

8. Ahmed DS (2010) Sustainable Forest Management, Biodiversity and Livelihoods. Montreal, IUCN-Convention on Biological Diversity, Canada.

9. Robin BA (2012) Sustainable Community Forest Management: A Practical Guide to FSC Group Certification for Smallholder Agroforests. Seattle, TFT, USA.

10. Cubbage F, Moore S, Henderson T, Araujo M (2009) Costs and benefits of forest certification in the Americas, Chap. 5, p. 155- 183 in Natural resources: Management, economic development and protection.

11.World Bank (2013) Managing Forest Resources for Sustainable Development, An Evaluation of World Bank Group Experience.

12. Lagan P, Mannan S, Matsubayashi H (2007) Sustainable use of tropical forests by reduced-impact logging in Deramakot Forest Reserve, Sabah, Malaysia. Ecological Research 22(3): 414-421

13. Quevedo L (2004) Draft Forest Certification in Bolivia. In: Forest Certification in Developing and Transitioning Societies: Social, Economic, and Ecological Effects.

14. Bass S, Thornber K, Markopoulos M, Roberts S, Grieg-Gran M (2001) Certification's Impacts on Forests, Stakeholders and Supply Chains. Instruments for Sustainable Private Sector Forestry Series.

15. Arun A, Cashore B, Hardin R, Shephered G, Catherine B, et al. (2013) Economic Contributions of Forests. Istanbul: United Nations Forum on Forests.

Your next submission with Juniper Publishers will reach you the below assets

- Quality Editorial service

- Swift Peer Review

- Reprints availability

- E-prints Service

- Manuscript Podcast for convenient understanding

- Global attainment for your research

- Manuscript accessibility in different formats

( Pdf, E-pub, Full Text, Audio)

- Unceasing customer service

Track the below URL for one-step submission https://juniperpublishers.com/online-submission.php 